\title{
Lucretia and the Impossibility of Female Republicanism in Margaret Cavendish's Sociable Letters
}

\author{
SANDRINE BERGÈS
}

Margaret Cavendish is known for her personal allegiance to monarchy in England. This is reflected in her writings; as Hobbes did, she tended to criticize severely any attempt at rebellion and did not think England could become a republic. Yet it seems that Cavendish did have sympathy with some republican values, in particular, as Lisa Walters has argued, with the republican concept of freedom as nondomination. How can we explain this apparent inconsistency? I believe that the answer lies in a lack of fit between the republican theories that were available to her and the values she accepted and according to which she was expected to live her life.

$[O]$ nly Collatinus finds his wife-though it were late in the night — spinning amongst her maids - Shakespeare, The Rape of Lucrece

It has been suggested in the wake of a revival of republican theories (neo-republicanism) that such theories are generally bad for women (Phillips 2000; Pateman 2007). This is in part due to the misogynist history of republicanism, and in part because republicanism is very much a matter of public performance, which relies on but does not always acknowledge the private labor of women. The suggestion that republicanism is bad for women, however, has been countered energetically and persuasively by scholars working on the history of republicanism in women authors such as Mary Wollstonecraft and Catharine Macaulay (Coffee 2014; Halldenius 2015; Coffee 2017).

But these historical studies are often contextual — and rightly so - and as such the conclusions drawn may fail to apply in different contexts, so that what was true for English women philosophers of the eighteenth century may not have been so for those of the seventeenth century. This means, for instance, that a seventeenth- 
century writer may have been less likely to be thoroughly acquainted with certain views, and lacked the opportunity to discuss them or the means to write about them. Certainly Cavendish's intellectual life, despite her husband's close acquaintance with Descartes and Hobbes, was more secluded than that of either Mary Wollstonecraft or Catharine Macaulay, who debated their theories much more freely with other leading thinkers of their times.

Although the fact of the historical difference in a woman's ability to engage with a particular tradition is generally interesting, republicanism is particularly prone to this because it does not simply theorize the state, or political authority, but encompasses in its study the characters of citizens, their modes of life and capacity for political engagement. Recall Aristotle's claim that the ideal citizen will have a confident voice and a long stride because these physical traits will assist him (and exclude her) from effective participation in the affairs of the polis.

It is likely, as Wollstonecraft and Macaulay scholars argue, that in the eighteenth century, republicanism was historically female as well as male, and this is important because it shows that neo-republicanism is at least viable for feminists. At the same time, it may be true that this was not the case in the seventeenth century, and that this difference is due to the social context in which republicanism was read and debated.

Such a conclusion would be interesting, as it would it show the extent to which republicanism's appeals to character, the conception of a citizen, and its conceptions of virtues make it time- and culture-dependent. Given the lasting appeal of republicanism, one might suppose that not all its characteristics vary across time, but that some republican virtues, at least, are universal. Given that the pillar of republicanism is the understanding of liberty as nondomination or independence, these universal characteristics would include, hopefully, the propensity of citizens to respect one another's independence. Such a propensity would, if unfettered by local prejudices, make for a fundamental sort of gender equality. A study of why republicanism failed to be appealing to a seventeenth-century woman philosopher who at the same time valued freedom and independence may help isolate those aspects of republicanism that transcend historical variation from those that belonged strictly to seventeenthcentury England.

\section{RePUBLICANISM AND WOMEN}

Republican politics is to a large extent a matter of public performance, one that puts citizens together on a level with one another, enabling conversation and contestation (Pettit 1999; Matthes 2000). It's about taking action and speaking in public. It's about daring to disagree and to propose alternatives. It's about leaving the home and walking to the agora, striding confidently, and speaking out in a deep voice (Aristotle 1999, 1125a13-16), or about metaphorically sitting down to eat and drink with Plutarch, Cicero, or Aristotle, and discussing politics with them unafraid, as an equal who has read their books, is familiar with their histories, and is prepared to take whatever actions they model or suggest (Coyle 1995, 198). 
Historically, very few women have been in a position to do all of those things (or any of them). Until very recently, women of leisure did not leave home unchaperoned, were not allowed to speak publicly, and did not receive a solid enough education that they could feel they were in a position to converse with classical authors. The ideals of republicanism were not for women, or not, at least, for rich idle women of England in the Civil War period. ${ }^{1}$

These appeals to character traits and even bodily traits have not completely disappeared from contemporary republican theories. They survive, for instance-even if to some extent, metaphorically - in Philip Pettit's description of the leading characteristic of a republican society as one in which every citizen can look other citizens in the eye "without reason for fear or deference that a power of interference might inspire; they can walk tall and assume the public status, objective and subjective of being equal in this regard with the best" (Pettit 2012, 84). Note that Pettit seems to be borrowing Aristotle's own imagery: his walking tall seems very much like Aristotle's long strides. This image also brings to mind another aspect of the eyeball test: to look someone in the eye comfortably, one needs to be unafraid, and there is definitely a physical side to this: one needs to be tall enough to look someone in the eye convincingly. For Pettit, this seems to be mostly about legal status: whether rich or poor, in a republic we are equal in front of the law. But of course, being equal in front of the law is not always sufficient for bringing about the sort of respect for one another that would result in the confidence necessary to look someone in the eyes. Avoiding eye contact is a strategy that many women use in order to protect themselves from potential assault. And forcing eye contact is sometimes a sign of forthcoming assault or harassment. Again, there is a worry that the eyeball test brings us back to a concept of republican citizenship that excludes women.

It is quite clear that republics of the past did not pass the eyeball test, except perhaps if one looked only at those who were counted as citizens, that is, excluding servants, women, and slaves. One might say that even a republic where a particular class of society passes the eyeball test is better than one in which nobody does. And it's arguable that in prerevolution France, for example, no one except the King could look everybody in the eye. Social relations were such that everyone-except the king counted as socially inferior to someone else.

If the eyeball test is to be significant and useful, it requires that there be some structures in place or easily put in place to enable people to step up or down so that they may be on the same level as one another. To some extent, these structures were already in place at the end of the eighteenth century in France as in England, so that political thinkers could contemplate the activation of republican principles. In particular, women could begin to contemplate this, to see a time when they would count as citizens too and be able to look men in the eye and discuss social and political reforms. This was not the case, however, in England circa the Civil War. What is clear from reading Cavendish is that she too thought that England was not ready for a republic. In Oration 153, "To Hinder a Rebellion," in which a king addresses his people on the brink of rebelling, she writes: "Yet put the case you should have victory, you will sooner make a confusion than settle the kingdom into a republic, for 
the nature and constitution is not for it, as having been bred up a long time to monarchy, so that you may sooner change the nature of man into a beast than the government of this kingdom into a republic" (Cavendish 2003, 267).

What Cavendish highlights here is not just that the country is not ready but that the people are not, that they have been shaped to live under a certain kind of government and cannot flourish under one that is radically different. It is not simply a matter of providing steppingstones for people in a lower social class so they may put themselves on a level with the aristocrats. They are, by (second) nature-that is, they have learned to be-incapable of looking an aristocrat in the eyes. They have not been taught to do this, and suddenly being put in a position where they might would not help. In that sense, Cavendish shares Wollstonecraft's distrust of sudden change. Wollstonecraft, although she is convinced that a "revolution in manners" is necessary for women to accede to independence, sees that the social and cultural prejudices keeping women in a state of dependence are so deeply entrenched that this revolution cannot be sudden: it has to be progressive, and it may take some time (Wollstonecraft 1993, 148). Clearly, Cavendish does not share such optimism, but makes it fairly clear that as far as she is concerned, monarchy is better than change.

The focus of this article is the extent to which republican values struck Cavendish as unworkable in her times, and in particular unattractive for women. But Cavendish does hold some positive views about freedom, especially concerning women, and also concerning the human condition more generally. Lisa Walters argues that her position on freedom situates Cavendish as part of the republican ideas that were at the center of the Civil War. According to her, Cavendish "articulates republican beliefs about tyrannicide, self-defence, natural rights and popular sovereignty" (Walters 2014, 195). Walters claims that these beliefs do amount to a defense of liberty against tyranny and that these views are especially manifest in Cavendish's plays and stories, in particular in a short story published in 1656, "Assaulted and Pursued Chastity." In this story, Cavendish describes the adventures of a rich and virtuous young lady, returning from exile to her family after a civil war, who is shipwrecked and captured for prostitution. The heroine takes up arms and threatens to kill her would-be rapist, even though he is a prince, and later engineers the freeing of an enslaved people. ${ }^{2}$ The claim that Cavendish found some republican values appealing does not suffice to make her a republican if she still believes that absolute monarchy is the best form of government - even if seventeenth-century republicans did not necessarily demand the end of monarchy, they at least required the end of absolute monarchy. It does, however, legitimize the project of this article, which is to ask why republicanism was unattractive to her, given that she did adopt some of its principles.

In section III, I investigate the differences between seventeenth- and an eighteenth-century perspectives on republicanism for women, focusing on Cavendish on the one hand and Marie-Jeanne Roland on the other, and highlighting the difference between those characteristics of republicanism that are universal and those that belong to a particular time. In the final section I investigate more closely the causes of Cavendish's skepticism regarding republicanism for women, focusing on her discussions of a particular Roman republican model for women, Lucretia. But before doing 
any of this, I will need to spend a bit of time examining Cavendish's relationship to the republican texts that she might have read, as this will help find the answers to the questions posed in sections III and IV.

\section{CAvendish as a Reader of the Classics}

Margaret Cavendish often deplores the fact that she did not receive a classical education and that she is therefore not in a position to engage with the classics in the way that her male contemporaries were (Cavendish 1664, preface). She learned her letters, but not her Greek letters, and given the scarcity of available translations of Greek and Latin texts, one might be tempted to concur with her about her ignorance, and peg her as an original and eccentric thinker who created every one of her thoughts and arguments from scratch (Whitaker 2002, 14). But the Sociable Letters show us that Cavendish was in fact a reader of the classics: English translations of Plutarch, Ovid, and Julius Caesar were available to her. ${ }^{3}$ She also had access to summaries and extracts of ancient texts through Thomas Stanley's History of Philosophy, which we know she had read at least in part, and which contained long extracts from, for instance, Xenophon (Schliesser 2016). Not knowing classical languages was also an obstacle to reading the books of her contemporaries, as many wrote in Latin, although many, such as Descartes and Hobbes, also ensured that their work was available in translation. ${ }^{4}$

History of philosophy, especially when it tries to be contextual, does rely to some extent on reception history. It helps to know what the frames of reference of philosophers were in order to understand their arguments better. This is especially true in the case of philosophers who don't fit neatly into a historical narrative, either because their works had only recently become widely known or because their contemporaries and the generations of readers that followed did not pay them the attention that they deserved. In the case of Cavendish, although she struggled to make a place for herself among her contemporaries, they did not welcome her, and she did not play a central role in philosophical debates of her times. And it is not until fairly recently that philosophers have begun to work on her texts in a philosophical manner. But such interest means that knowing what Cavendish's influences were matters, and if we are interested in what she had read, then the Sociable Letters is a very useful source. Not only does it discuss Cavendish's own reading practices, and present her critique of works she had read, but it also focuses on how reading affected women's lives: Sociable Letters "explores many aspects of women's social lives, but primary among its concerns is the representation and analysis of the variety of women's literary practices." 5

Research in the history of reading suggests that early modern readers of the classics tended to read works on political theory and history "for action," that is, theirs was "a close and informed reading, with a diplomatic or political end in mind" (Jardine and Grafton 1990, 44). They looked in the texts for a model of how a virtuous subject or citizen should act, and sought to imitate the actions depicted in those 
texts, to study strategy or government. Aristotle's and Cicero's Constitutions were thought of as models, Livy's History as a textbook for when to obey and when to rebel, Plutarch's Lives as a model and inspiration for virtue.

One particular and popular way of reading ancient political theory and history was to study the history of republics, as Machiavelli and Harrington did, and draw conclusions that may be useful for contemporary politics (Richard 2015, 135). For readers whose contemporary political organization was monarchical, this could easily lead to thoughts of rebellion. And this was indeed Hobbes's worry when he commented that a classical education could easily lead to the desire to rebel against the king, and ultimately, to violent uprisings.

And by reading of these Greek and Latine authors, men from their childhood have gotten a habit, (under a false shew of liberty) of favouring tumults, and of licentious controlling of the actions of their sovereigns; and again of controlling those controllers, with the effusion of so much blood; as I think I may truly say, there was never a thing so deerly bought as these western parts have bought the learning of the Greek and Latine tongues. (Hobbes 1995, 111)

As far as Hobbes was concerned, the texts of Livy or Plutarch were ill-suited to reading for action, as readers would become enthused by the exalted virtues of the heroes depicted and by the excitement of the battles described, and be encouraged to act in whatever rash way presented itself to them and seemed remotely like that which the Roman writers depicted.

And as to Rebellion in particular against Monarchy one of the most frequent causes of it is the reading of books of policy and histories of the Ancient Greeks and Romans; from which young men, and all others that are unprovided of the Antidote of solid reason receiving a strong and delightful impression, of the great exploits of warre, achieved by the conductors of their armies, receive with all a pleasing idea of all they have done besides .... From the reading, I say, of such books men have undertook to kill their kings. (Hobbes 1995, 171)

Hobbes, it might be said, is of the school that now thinks violent novels, movies, or video games encourage violent behavior. And we might be tempted to dismiss his claims just as we would the claim that reading Camus encourages murder or suicide. However, the context in which Hobbes is writing gives his claim more plausibility. If readers read for action, then it is to be expected that they should model their behavior on what they read. We, on the other hand, tend to read (fiction, at least), watch movies, or play games for distraction or entertainment. No one watches a George Romero film in order to learn how to survive a zombie apocalypse. If a viewer were to come out of the cinema and either attempt to behave like a zombie or like a survivor attacking a zombie, this would not be the result anticipated. Thus the arguments that we might deploy against the sort of ethical criticism that claims art and media are direct influences on criminal behavior do not apply to Hobbes. Hobbes did 
not write about reading for fun, but about reading for action, which gives the books that are being read in that way a much more powerful influence.

A worry one might legitimately have if young people treat books centuries old as political manuals is that the examples they use as models are no longer relevant to the situation in which they are called to act. That is, they describe people and states that are too distant in time and space for it to be possible to extrapolate anything useful. Especially if these books were not written as models for foreign states in the distant future, it is likely that they would pay attention to the specifics of the situations they described, and match their political advice to these specifics. A seventeenth-century politician following advice taken from a book written more than a thousand years before in a different land would be taking the very real risk of entirely misapplying the advice delivered in the book. In this way, historical irrelevance is just as dangerous as exalted descriptions of battles.

This is a problem that Cavendish notes in Sociable Letters, and in a play, The Sociable Companions (written four years after Sociable Letters, in 1668). In the play, a young man is being dissuaded by his friends from reading the classics: "Why such Books, since you are neither Greek nor Roman? So that those Histories, or Historians of other Nations will not benefit thee, nor thy Native Country for the Laws, Customs or Humours; for what are the Laws, Customs, Humours and Conventions of the Romans, Greeks, Turks, or Persians to thee or thy Native Country?" (Cavendish 2002, 134). It is clear that what Cavendish is criticizing here is not merely the practice of reading for action, but the choice of ancient texts as models. If one reads such texts for actions, then one is bound to act in such ways as may have been beneficial at the time and the place for which they were written but not for the reader's country, time, or even his personal life. Using the actions depicted in these books as models will not only be useless but also potentially harmful.

In Sociable Letters 54, Cavendish appeals to a similar argument with respect to the story of Lucretia. She describes a fight that the writer witnesses between two ladies on the reason for Lucretia's suicide. The ladies are coming to blows and the writer fears they might kill each other. She begs them to stop, considering the irrelevance of the story to their lives and situation:

[A]nd give me leave, Ladies, said I, to ask you what Lucretia was to either of you? Was she of your Acquaintance or Kindred or Friend, or Neighbour, or Nation? And if she was none of these, as it was very probable she was not, Living and Dying in an Age so long afore this, nay, so long, as the Truth might Rationally be questioned, if not of the Person, yet of the Manner of the Action, for perchance the clear Truth was never recorded, Falshood having been written in Histories of much later Times than that of Lucretia; therefore Allay your Passions, for why should you two Ladies fall out, and become Enemies for Lucretia's sake, whom you never knew or heard of, but as in an old Wife's Tale, which is an old History. But Howsoever, Good Ladies, said I, leave Lucretia to live and dye in History, 
and be you two Friends in present Life, Abuse not your selves with Rage, concerning Tarquin's Abusing Lucretia with Lust. (Cavendish 1997, 65)

This is quite the harangue; Cavendish makes a great deal of the fact that Lucretia's story is "old news" and that the readers have no particular reason to take it seriously or to consider its implications for their own lives. What happened to Lucretia after she was raped was shaped to a large extent by Roman laws regarding chastity and marriage. Lucretia kills herself because the penalty for adultery is death. And although the same was still true in England at the time Cavendish was writing, things were very different in practice, and adultery was regarded as somewhat fashionableat least in London. In any case, it is hard to see how such stern virtue as Lucretia's could make much of an impression on seventeenth-century English ladies. Indeed, even when Machiavelli rewrote the story as a contemporary play, it became a farce where Lucretia cheats on her husband for the sake of the Republic, and where no one dies (Matthes 2000, 82).

Cavendish thus again makes the point that we should ask ourselves whether a text is at all relevant to us before becoming enthusiastically involved in its political interpretation. But she is also doing something else when she advises the two ladies who read the story of Lucretia. Namely, Cavendish is expressing a degree of skepticism about the truth of the story and at the same time questioning the reliability of all historical writings. The story of Lucretia is, after all, a myth, one that has been reported by many writers, each time with some variation, and which seventeenth-century readers have no way of corroborating. And, Cavendish points out, most historical writing available to her contemporaries is unreliable, for one reason or another, and it is not possible to corroborate the facts and stories they relate. Given this, it would be unwise to treat history as a model for political action (or indeed any sort of action).

In Cavendish as in Hobbes, therefore, there is an element of mistrust as well as an element of irrelevance. Both believe we should not give our admiration and credence to ancient texts too easily as a) they cannot be trusted and b) their distance from us, culturally, geographically, and historically, means that they cannot easily be transferred to policies for our times.

For Hobbes, reading ancient texts is not merely useless or misleading, but also dangerous. Men, he says, who read the classics go on to wage war, in particular civil war, and to challenge authority at the cost of many lives. One might think that Cavendish is trying at the same time to express what Hobbes is expressing: the ladies disagreeing about Lucretia in Letter 54 have come to blows and are on the brink of killing each other. This may be better understood, it is true, as a form of parody: the idea that one lady should come to fear for the lives of two others who are having an academic disagreement is hard to take seriously. But perhaps Cavendish is thinking of a different way in which women readers may be endangered by Lucretia, that is, by encouraging them to commit suicide, a form of violence that not only took lives, but also souls, as suicide was described by the church as self-murder.

The story of Lucretia is told by Livy, and repeated by Plutarch, among others, though not in the Parallel Lives that served to encourage young men toward rebellion, 
but in a text that served as reading for women: the Morals, which presented the lives of virtuous women of ancient times, such as Lucretia. ${ }^{6}$ Cavendish refers to Lucretia explicitly in at least two places. She discusses her in Sociable Letters 54, as discussed above, and there is a reference to Lucretia in the World's Olio, in which Cavendish blames Collatine, the husband, for bragging about his wife's virtue, and being indirectly responsible for her rape and suicide. There is also, as I will argue in a later section, an indirect reference to Lucretia in Letter 150, in which the writer contemplates sitting down to spin with her maids (which was a well-known trope in all versions of the Lucretia story).

Seventeenth-century women were not supposed to read the texts that would encourage rebellion, but those that teach them docility and the domestic virtues. Yet it is by reading about Lucretia that two ladies end up in a physical fight. Perhaps the point of Letter 54 is to comment on the difference between the supposed effects on a man of reading the classics, which seems to be Hobbes's main concern (although he does allow that others may read them-older men, or women?) and on a woman, such as herself, who is not content with the readings she might be directed to, and who, in any case, may find herself in the way of the very same danger by reading those specifically "feminine" texts.

\section{Reluctant Fan-Girls: Cavendish and Roland}

Given that the way in which early modern men tended to read the classics was to seek models for action, it seems that male and female reading practices or the texts they read must have been different. A woman reader would not have been perusing Plutarch looking for military tips. And indeed, women were not supposed to read Plutarch, or at least not those of his books that dealt with military virtues. Women's readings were supposed to bring them closer to home, showing them portraits of virtuous women of antiquity, and holding them up as examples. So in a sense male and female reading practices were the same: both had to seek exemplars and adjust their lives accordingly, but given the passivity of female exemplars, a woman's reading could hardly be described as being "for action." Citing Thomas Salter, the author of The Mirror of Modestie, Dodds outlines what a seventeenth-century woman's reading should be about: seeking to become more like the virtuous Roman women depicted in Plutarch's Morals, turning their attention to developing their wifely and homemaking virtues (Dodds 2013, 48).

The women of Plutarch's Morals are, no doubt, admirable: they display courage and strong principles as well as more passive virtues, but can they really inspire a reader whose ambitions go beyond being a good wife and mother? When Cavendish talks about the military leaders of Plutarch's Lives, she tells us she not only admires but also envies them. In Letter 27 she tells us:

[T]o fight valiantly, to suffer patiently, to govern justly, and to speak rationally, movingly, timely and properly, as to the purpose, all which I 
fear women are not capable of, and the despair thereof makes me envy or emulate men ..... And of all the men I read of, I emulate Julius Caesar most, because he was a man that had all these excellencies, as courage, prudence, wit and eloquence in great perfection. (Cavendish 1997, 37-38)

If what is attractive to her is the capacity to lead, and the education that makes it possible to do so well, then it is unlikely that she would be attracted to the virtuous wives of the men she reads about in Plutarch.

Though Plutarch did write about one woman whose character flourished beyond the home, this woman is not the kind to inspire envy in Cavendish. Aspasia, the mistress of Pericles, may be skilled and educated in such a way that she can play a leadership role in politics, but the fact that she is not virtuous (she was a hetaira, a high-class prostitute) negates her potential as a role model. No seventeenth-century woman can hope to be an influence for the good if she cannot at least maintain a reputation of chastity (though it need be no more than a reputation).

So Cavendish is in a quandary: the virtues praised in men are not virtues she should emulate as a woman. But the virtues praised in women are not those she is drawn to emulate. Supporting republicanism would mean being in favor of a model that she is explicitly told that she cannot follow without becoming a social outcast.

An interesting parallel can be drawn with another female reader of Plutarch, who wrote in France a little over a century later. Marie-Jeanne Roland, who died during the Terror in 1793, was an engaged republican writer. Like Cavendish, she recognized that Roman classical republicanism depended on a division of virtues into male and female. But unlike Cavendish, she found a way to reconcile this at least partly with the possibility of active citizenship as a woman. Roland had read and admired Plutarch's Lives as a child, and her first response to it was to wish she were not a woman living in the eighteenth century. At the age of eight, she took the Lives instead of her prayer book to church. At twelve, she cried that she had not been born Roman or Spartan so that she could have lived in a republic (Roland 1905, 48), a feeling she remembered at twenty-two when she wrote, in a letter to a friend, that if she could not be born Roman or Spartan, at least being a man would be better (Roland 1913, 274).

As she grew older, Roland read Rousseau, which first confirmed her republican views and reinforced her desire that she should have been born a man, but later, as she read his New Heloise, led her to embrace a division of male and female virtues, which meant that she could admire male virtues but aspire to female ones. This marked a turn in her intellectual development, one that helped reconcile her with the life of an intellectual and politically engaged domestic wife and mother, at least until the revolution called her out of her home and led her to take a more active role again.

Rousseau was in favor of a "rural" republicanism, that is, a republic built from homes and villages populated by peasants who lived simple and healthy lives, focusing on virtues and necessities, rather than the luxury and excitement sought by city dwellers. In his Constitutional Project for Corsica, Rousseau argued that a rural style 
was more beneficial for a republic both because it produced healthier citizens (away from the depraved lifestyle of the city that led to disease and infertility) and because the attachment of peasants to their land translated easily into patriotism, thereby making it easier to turn the population into one of active and committed citizens (Rousseau 1763, 10).

Adopting a Rousseau-style rural republicanism made it possible for Roland to reconcile her predilection for republics and her view that men and women had different and complementary virtues (Bergès 2016). A focus on a simple lifestyle and an emphasis on the importance of home life enabled her to appreciate the role that women of antiquity may have played in the building of republics. Writing about Spartan women's lives, she said:

More sedentary, more enclosed ordinarily in republican governments, left to domestic tasks, nourished by this patriotism that elevates the soul and sentiments, they labored toward the citizen's happiness and that of the state, through the peace and order reigning inside their homes, and the care they take to cultivate in their children the germs of courage and virtues that must perpetuate as well as liberty. ${ }^{7}$

This attempt to find a place for modest and laborious housewives in the life of the republic, however, was not entirely successful. Even if a republic could be nurtured principally from within individual homes, it is clear that this is not how it is created - unless the homes in question be Parisian salons like that of the Condorcets, Mme. de Stael, or indeed, Madame Roland herself. When the revolution came, Roland lost the ability to be fulfilled by domestic virtues alone, and decided that she too must participate (Roland 1900, vol. 2, 307).

Roland, much as Cavendish did, wavered between wanting to embrace the example of manly virtues depicted in the classics and shying away from them because she was a woman. But whereas Cavendish found little to admire in the portrait of ancient women, Roland thought she could emulate them. For Roland, the Spartan women she describes are just as much the guarantors of republican freedom as their soldier husbands. For Roland, a republic is built in the home, by nurturing certain values and virtues, and embracing a simple life that will not invite corruption through a love of luxury. In order for such a life to be at all appealing, women must ensure not only that their children are brought up with the right sort of character, that they learn to care for things other than what can be bought for money, or be had in cities, and that they must also make a simple home life appealing enough that men will not stray and children will not want to leave and go to the city as soon as they are old enough.

What would have made a difference in Roland's and Cavendish's reception of ancient republican women was in part the framework in which republican women were presented to them. For Cavendish, they were merely the ornaments that republican men kept at home, and occasionally displayed to one another. For Roland, they were not merely the preservers of republican values, but were the creators of them, in their homes. Nor were they mere ornaments: Spartan women and Rousseau's women 
were not city dwellers; they lived a simple, rural life, working for their families, and nurturing the characters of those who would later become citizens. In Roland's case, the context of the revolution also mattered, as in the late eighteenth century, it was not impossible to imagine that women too would become citizens, and be offered the chance to participate more actively in their own government, while being responsible for the growth of republican virtues and sentiments at home.

Given all this, it is understandable that Roland would have valued at some point a more passive, homebound lifestyle, and that as a result she would have found ancient republican wives a suitable model. The republican model that Cavendish is familiar with, however, is not obviously a rural one. It is one that focuses on wars, revolts, and political negotiations. Plutarch's women do display the sort of virtues that one would expect to find in Rousseau's or Roland's rural republican women, but it is less clear that they are, through these virtues, contributing directly to the growth of the republic. They are merely providing a stable and virtuous home for their politically involved husbands to return to. Given this, there is very little reason to expect that Cavendish would be attracted to the lifestyle of women who bear their domestic duties simply because they know they are making it easier for their husbands to support the republic.

The fact that the distance between the manly virtues of "action" and the housewifely ones of "nurture" seems to become less between the seventeenth and the eighteenth centuries also gives pause for thought. Are these virtues manifestations of the way in which a given society functions, and distributed accordingly at different periods in time? Are they simply possible manifestations of the overall requirement that republicans should be guided by reason and should respect one another's independence in all their actions? If so, it is the fluidity and adaptability of republican virtues that makes for such different manifestations in different historical periods. More important, whether these virtues contribute to a political theory that is attractive to women will depend in large part on existing social structures and the gender parity they enable.

\section{Reliving Hipparchia's Choice and Lucretia's Tragedy}

In this final section, I would like to investigate more closely the model of female republican virtues Cavendish is rejecting, and why she is rejecting it. This can be done through a reading of her Sociable Letters, where she addresses social and political issues from the perspective of an aristocratic woman. In particular, I will look at letter 150 .

In Sociable Letters 150, which has strong autobiographical overtones, the author finds herself under fire from her neighbors, who claim that because she spends her time in her room alone writing, her maids remain idle, and therefore prone to misbehavior. She decides that in order to stop the gossip and be seen to do her duty as the mistress of the house, she will take up spinning, and that her maids will join her. Upon hearing her decision, her house governess mocks her gently and says that she will just waste flax if she spins, or silk if she makes silk flowers, or sugar if she makes 
preserves. She will also waste everyone's time, and no one will be happier as a result. It will be better, the governess says, if the author sticks to writing-as she has a natural gift for it - and if her maids stick to reading books, which they enjoy and which will improve them, not spoil them as the neighbors claim. The neighbors can and should be ignored.

This letter is striking in several respects. First, Cavendish is portraying herself (if the letter is indeed autobiographical) as someone who is completely ignorant of "huswifry," in that she has not been taught to spin by her mother, not been expected to do any by her husband, nor been pressured by friends, relatives, or neighbors (until now) to do it. Of course, as that of a very aristocratic lady, her education need not have involved anything "useful" that could be performed by someone paid for it. As she states earlier, in Sociable Letters 26, the instruction of aristocratic women is "only to dance, sing and fiddle, to write complimentary letters and to read romances." It may be superficial, "an education of the body and not of the mind," but it is certainly not practical, nor housewifely.

Second, it is interesting that Cavendish's first choice of an industrious activity to perform with her maids is spinning. Spinning was not a common pastime among aristocratic English women in the seventeenth century - it was a job that poor women did to earn money. The story told in Letter 150 is almost certainly chosen to bring to mind the story of Lucretia, surprised by her husband and his friends spinning with her maids, while the other wives in the story used their husband's absence to host parties. This picture of Lucretia spinning among her maids was a common trope, one that Cavendish and her contemporaries would have been familiar with from reading Shakespeare, Ovid, and Plutarch's Morals.

Although Cavendish does not refer to Lucretia in Sociable Letters 150, she concludes with a reference to another domestic craftswoman of antiquity, Penelope, saying that had Penelope been writing instead of weaving as she waited for her husband, this would have engaged her mind completely, and her suitors, seeing they could not communicate with her, would have left, instead of becoming permanent and expensive guests. Weaving, Cavendish says, occupies only the hands, but not the mind, therefore it does not truly engage its practitioner. In Penelope's case, this meant that she was able to flirt with her suitors, but possibly Cavendish is also responding to allegations of laziness: writing engages her fully, mind and body, so it has to count as work in a way that spinning or any other sort of crafts activity could not. This passage makes it quite clear, incidentally, that she is truly ignorant of craft activities, and is as a result perhaps unfair to Penelope.

Yet another spinner from antiquity comes to mind when we read this letter, namely Hipparchia, who once tried to behave like a traditional Greek wife and spun a coat for her husband, Crates. The coat was returned with instructions that she should go back to study and not waste time with household duties. It is not clear whether Cavendish would have known of Hipparchia's story. Yet there is a sense in which this story mirrors the dilemma of women philosophers throughout the agesbe a respectable member of one's society or pursue intellectual work-and, clearly, this is the dilemma Cavendish presents in Letter 150. 
The story of Lucretia is not merely an exemplar for virtuous women. At least in the version told by Livy, it has strong ties to the founding story of Rome. Upon finding her so virtuous as to be spinning with her maids while her husband was supposed to be away, Tarquinius Sextus decided to seduce her, which led to him raping her, and to her eventual suicide. Her death was, according to Livy, what prompted Rome to become a republic. This might be cause enough for Cavendish's skepticism as to the pedagogical value of the story. It is one thing to embrace a heroic death through one's courage and honesty, and quite another to kill oneself to protect one's chastity (and spinning skills). And it is yet another to claim that this act constituted a foundation for a constitution that embraced liberty against tyranny. Not only might one strongly object to such an act of criminal violence being held as politically foundational, but also one might reasonably doubt whether it in fact was. As Cavendish tells us: "for perchance the clear Truth was never recorded."

If Cavendish was skeptical about the role played by the rape and suicide of Lucretia in the history of the Roman republic, she was not alone. Interestingly, she shares this outlook with a writer who was a lot more reliant on the political theories to be found in Roman books, Machiavelli. In particular, Machiavelli didn't believe that the rape of Lucretia was instrumental in the founding of the Roman republic:

Tarquin was driven from Rome not because his son Sextus had violated Lucretia, but because he had disregarded the laws of the kingdom and governed it tyrannically .... If the accident of Lucretia had not occurred, some other would have produced the same effect; for had Tarquin conducted himself like previous kings, when his son Sextus committed that crime, Brutus and Collatinus would have appealed to Tarquin for vengeance against Sextus, instead of stirring up the Roman people as they did. (Machiavelli 2007, 257)

One might flinch at the casual reference to the "accident" of Lucretia's rape. However, "accidente" does not here suggest that no one was to blame, but that the rape itself belonged to the sphere of Fortuna, the dangerous and irrational. Although it is true that there is violence (not just against women) in many of Machiavelli's founding stories (Matthes 2000, 85), what transpires from Machiavelli's account of Lucretia's story is that he will not mythologize her rape. What happened to her remains an ugly crime, one that the Romans would have come to expect under a ruler such as Tarquinius Superbus. So the rape of Lucretia is not historically significant qua rape of Lucretia, but qua "accident" of fate that brought about the opportunity for change (McCormick 1993).

The violence of the myth of Lucretia is a very clear reason why Cavendish may not have felt it was an appropriate example for women to turn to: whereas the men of Plutarch wreak havoc, and when they die, do so heroically, Lucretia is the victim of sexual violence and then is compelled by the rules of society to take her own life in order to safeguard her reputation as a wife. This hardly seems inspiring or worth emulating. But not only is the story of Lucretia one of violence against women, and of exclusion - the republic is founded on her dead body! - but it was also touted as a 
tale of immorality: Lucretia, as Augustine points out, commits suicide, which is considered a sin by all Christians - even seventeenth-century Anglicans. If Lucretia was the kind of person capable of murdering an innocent (as Augustine puts it) then she is hardly a model of virtue for English wives. In short, there seems very little in the story of Lucretia for Cavendish to admire, and even less to emulate.

One century later, the women of Greek and Roman antiquity were upheld as exemplars by republican thinkers such as Jean-Jacques Rousseau and Marie-Jeanne Roland, but their republican qualities were again very different from the ones Cavendish admired in the men, as they were confined to the household, and were responsible mainly for the production and virtuous breeding of future republican citizens. As a Roman or Spartan republican wife, she would indeed have spent time spinning that she would rather have spent writing. None of this must have escaped Cavendish, who would have been aware that women's increased participation in politics on the Levellers' side came with a tightening of their roles: a Leveller wife may have had a say in the political debates, but she was also less likely to be idle at home.

Conversely, it may have seemed to Cavendish that monarchy afforded aristocratic women more freedom to spend their time as they wished. As she says in Sociable Letters 16, women in a monarchy are not part of the system. They are not citizens, nor subjects of the king, and only barely subjects to their husbands. This means that although they have no legal standing, which has the potential to render them "more enslaved than any other creature," they are also not accountable, and have no duty to perform that will serve the kingdom. In other words, provided they can either persuade their husbands to leave them alone, or find safe ways of disregarding their orders, they can do as they please.

Historical republicanism, it seems, has always relied on some gender distinction, in particular regarding the roles that male and female citizens were expected to play in the republic. The model, originating in the Roman republic (and inspired in turns by Athenian politics), puts women in charge of the home and men of the public domain. This is consolidated by the fact that republicanism requires its citizens to have a certain character, to develop certain virtues, and relies on the home as the locus of virtuous education. Whether this sort of republicanism is attractive to women, therefore, will depend in great part on what sort of role they are expected to play in the home. In the case of Madame Roland, being in charge of the home meant being the intellectual and moral leader of a generation of revolutionary men: she kept a salon, set the intellectual and moral tone of two governments, and documented everything in her memoirs for posterity. The home, when it becomes a revolutionary salon, is not a bad place to be. Roland could truly claim that, in her family's case, republican values were not only nurtured but also created at home.

For Roland's contemporary, Wollstonecraft, republican women also have a gendered role: mothers must be in charge of feeding infants, and educating them (Wollstonecraft 1993, 227). But Wollstonecraft is looking to the future: she does not believe that it is possible for women in her time to be good republican wives or mothers. She believes that, first, they must be given independence, and that only once they are free from domination can they hope to become virtuous citizens. 
Neither the exceptional circumstances of the French Revolution nor the hope and optimism of Wollstonecraft (a product of the same exceptional circumstances) applied in Cavendish's case. All she saw was the original model: Lucretia, the virtuous citizen, is raped and has to kill herself. Although she too lived through some exceptional circumstances, she saw nothing to convince her that women would be better off under a republican regime-the exception was different, but the rule remained the same: in a republic, women can contribute to the general good only by staying home. Her reluctance to embrace republican values highlights the fundamentally unequal and at the same time essentialist take of historical republicanism on gender roles. It would be good for those of us concerned to reconcile republicanism with feminism to bear this in mind.

\section{NOTES}

I am grateful to Lars Vinx and Bill Wringe for their careful comments on an earlier draft, to Eric Schliesser and the audience of the Duke New Narratives conference in April 2016, and to two anonymous referees.

1. Leveller women were in a different position. See Hill 1984, 321-23.

2. Karen Detlefsen also argues that Cavendish held a view of freedom that was closer to a republican one than a Hobbesian one (Detlefsen 2012).

3. Lara Dodds suggests that Cavendish was probably reading the translation of the Lives by Thomas North, which Shakespeare had read. See Dodds 2013, 38.

4. We know, for instance, from the Epilogue to her Philosophical Opinions, that Cavendish read Hobbes's De Cive.

5. These claims rely on the assumption that Cavendish is speaking in her own voice in the Sociable Letters. But given that some of these letters were simply copied from her private correspondence, this is not a particularly controversial assumption to make. See Dodds 2013, 30.

6. See Dodds 2013, 48. There are many other retellings of the story, several of which Cavendish may have been familiar with, including by Augustine, Boccaccio, Christine de Pisan, Machiavelli, and Shakespeare.

7. My translation. "Plus sédentaires et plus renfermées, pour l'ordinaire, dans les gouvernements républicains, livrées aux travaux domestiques, nourries de ce patriotisme qui élève l'âme et les sentiments, elles travaillent au bonheur du citoyen et à celui de l'Etat par le bon ordre et la paix qu'elles font régner dans l'intérieur des maisons, et par le soin qu'elles prennent de cultiver dans leurs enfants ces germes de courage et de vertu qui doivent perpétuer l'un et l'autre avec la liberté" (Roland 1864, 344).

\section{REFERENCES}

Aristotle. 1999. Nicomachean ethics, ed. Terence Irwin. 2nd ed. Indianapolis, Ind.: Hackett Pub. Co. 
Bergès, Sandrine. 2016. A republican housewife: Marie-Jeanne Phlipon Roland on women's political role. Hypatia 31 (1): 107-22.

Cavendish, Margaret. 1664. Philosophical letters: Or modest reflections upon some opinions in natural philosophy maintained by several Famous and learned authors of this age, expressed by way of letters (London).

- 1997. Sociable letters, ed. James Fitzmaurice. New York: Routledge.

. 2002. The sociable companions. In Bell in campo and the sociable companions, ed. Alexandra Bennett. Peterborough, Ont.: Broadview Press.

- 2003. Margaret Cavendish: Political writings, ed. Susan James. Cambridge, UK: Cambridge University Press.

Coffee, Alan. 2014. Freedom as independence: Mary Wollstonecraft and the grand blessing of life. Hypatia 29 (4): 908-24.

- 2017. Catharine Macaulay's republican conception of social and political liberty. Political Studies 65 (4): 844-59. http://journals.sagepub.com/doi/abs/10.1177/ 0032321716686991 (accessed April 5, 2018).

Coyle, Martin, ed. 1995. Niccolo Machiavelli's The Prince: New interdisciplinary essays. Manchester, UK: Manchester University Press.

Detlefsen, Karen. 2012. Margaret Cavendish and Thomas Hobbes on freedom, education, and women. In Feminist interpretations of Thomas Hobbes, ed. Nancy J. Hirschmann and Joanne H. Wright. University Park: Pennsylvania State University Press.

Dodds, Lara. 2013. The literary invention of Margaret Cavendish. Pittsburgh: Duquesne University Press.

Halldenius, Lena. 2015. Mary Wollstonecraft and feminist republicanism. London: Pickering $\&$ Chatto.

Hill, Christopher. 1984. The world turned upside down: Radical ideas during the English Revolution. London: Penguin.

Hobbes, Thomas. 1995. Leviathan. London: Penguin.

Jardine, Lisa, and Anthony Grafton. 1990. "Studied for action": How Gabriel Harvey read his Livy. Past and Present 129 (November): 30-78.

Machiavelli, Niccolo. 2007. Discourses on Livy. Trans. Ninian Hill Thomson. Mineola, N.Y.: Dover Publications.

Matthes, Melissa. 2000. The rape of Lucretia and the founding of republics: Readings in Livy, Machiavelli, and Rousseau. University Park: Penn State University Press.

McCormick, John P. 1993. Addressing the political exception: Machiavelli's "accidents" and the mixed regime. American Political Science Review 87 (4): 888-900.

Pateman, Carole. 2007. Why republicanism? Basic Income Studies 2 (2): 1-6.

Pettit, Philip. 1999. Republican freedom and contestatory democratization. In Democracy's value, ed. Ian Shapiro and Casiano Hacker-Cordon. Cambridge, UK: Cambridge University Press.

- 2012. On the people's terms. Cambridge, UK: Cambridge University Press.

Phillips, Anne. 2000. Feminism and republicanism: Is this a plausible alliance? Journal of Political Philosophy 8 (2): 279-93.

Richard, Carl J. 2015. Cicero and the American founders. In Brill's companion to the reception of Cicero, ed. William H. F. Altman. Leiden: Brill. 
Roland, M.-J. 1864, ed. Mémoires de Madame Roland, 2 vols., ed. François Alphonse Faugères. Paris: Hachette.

- 1900. Lettres de Madame Roland (1780-1793) 2 vols., ed. Claude Perroud. Paris: Imprimerie Nationale.

1905. Mémoires de Madame Roland, ed. Claude Perroud. Paris: Plon.

1913. Lettres de Madame Roland (1767-1780), ed. Claude Perroud. Paris: Imprimerie Nationale.

Rousseau, Jean-Jacques. 1763. Projet de constitution pour la Corse. Digitized by Jean-Marie Tremblay for "Les classiques des sciences sociales," Université du Quebec à Chicoutimi: Bibliothèque Paul-Emile-Boulet. http://bibliotheque.uqac.uquebec.ca/index.htm (accessed January 22, 2018).

Schliesser, Eric. 2016. On discovering a political philosopher (by commenting): Cavendish \& Xenophon. Digressions $\mathcal{E}$ Impressions, April 20. http://digressionsnimpres sions.typepad.com/digressionsimpressions/2016/04/on-discovering-a-political-philo sopher-by-commenting.html (accessed January 22, 2018).

Walters, Lisa. 2014. Margaret Cavendish: Gender, science and politics. Cambridge, UK: Cambridge University Press.

Whitaker, Katie. 2002. Mad Madge: The life of Margaret, Duchess of Newcastle. New York: Basic Books.

Wollstonecraft, Mary. 1993. A vindication of the rights of woman, (1792) a vindication of the rights of men (1790). Oxford: Oxford University Press. 